\title{
ANALISIS KESULITAN BELAJAR MATEMATIKA SISWA KELAS V SEKOLAH DASAR KOTA BALIKPAPAN PADA MATERI SATUAN WAKTU TAHUN AJARAN 2015/2016
}

\author{
Rahayu Sri Waskitoningtyas \\ Program Studi Pendidikan Matematika, Universitas Balikpapan \\ e-mail : tyasrahayu3@gmail.co.id
}

\begin{abstract}
This study is meant to describe: a) The difficulty faced by fifth grader of Balikpapan City in learning mathematics especially in learning about "Time Unit". b). the reasons behind those difficulty faced by the students of fifth grade of Balikpapan City in learning "Time Unit". the type and approache of the research are descriptive with qualitative approach. The data collection method used in this research are documentation, test, observation and Questionnaire. Based on the final analysis data, the researcher found that the difficulty percentage faced by the students in factual is $14,4 \%$, the difficulty face in conceptual is $56,9 \%$, the difficulty in skills is $42,2 \%$ and the difficulty faced by the students in principal is $76,7 \%$. The causes of those difficulty in learning comes from inside and outside of students themselves. It is hoped that teacher can drill students in mastering the concept, skills and principal of "Time Unit" in the hope to reduce the students' difficulty in mastering the Time Unit material.
\end{abstract}

Key Words: Difficulty, Learning, Mathematics.

\begin{abstract}
Abstrak : Penelitian ini bertujuan untuk mendeskripsikan: (a) letak kesulitan belajar matematika siswa kelas V Sekolah Dasar Kota Balikapan pada materi satuan waktu dan (b) faktor-faktor yang menyebabkan kesulitan belajar matematika siswa kelas V Sekolah Dasar pada materi satuan waktu. Jenis dan pendekatan dalam penelitian ini adalah jenis penelitian deskriptif dengan pendekatan kualitatif. Metode pengumpulan data yang digunakan adalah metode dokumentasi, tes, observasi dan angket. Dari data hasil tes analisis akhir diperoleh persentase kesulitan peserta didik dalam fakta sebesar 14,4\%, kesulitan siswa dalam konsep sebesar 56,9\%, kesulitan siswa dalam keterampilan sebesar 42,2\% dan kesulitan siswa dalam prinsip sebesar $76,7 \%$. Faktor-faktor yang menyebabkan peserta didik mengalami kesulitan dalam belajar yaitu faktor intern dan ekstern. Diharapkan guru dalam memberikan materi satuan waktu lebih menekankan terhadap penguasaan konsep, keterampilan dan prinsip kepada siswa. Sehingga kesulitan siswa pada materi satuan waktu sedikit teratasi.
\end{abstract}

Kata Kunci: Kesulitan, Belajar, Matematika

\section{PENDAHULUAN}

Perkembangan ilmu pengetahuan dan teknologi mencakup peningkatan ilmu terapan dan ilmu pengetahuan dasar. Salah satu upaya meningkatkan kemampuan penguasaan ilmu pengetahuan dasar adalah dengan meningkatkan kemampuan dalam bidang matematika.

Ilmu matematika merupakan ilmu yang dipelajari peserta didik mulai dari tingkat sekolah dasar, menengah sampai universitas yang penekanannya pada pemahaman konsep dan struktur-struktur. Pentingnya ilmu matematika dalam kehidupan sehari-hari dapat meningkatkan kemampuan peserta didik dalam memahami dan menyerap pelajaran lebih cepat, selain itu dapat melatih kemampuan peserta didik untuk 
berpikir rasional, kritis, logis, analitis, dan sistematis.

Matematika digunakan secara luas dalam berbagai bidang kehidupan, diharapkan pembelajaran matematika di kelas bisa dikemas sedemikian rupa sehingga siswa bisa belajar secara optimal dan pada akhirnya mendapatkan hasil yang maksimal. Untuk itulah, diperlukan berbagai upaya atau usaha para pendidik matematika, bagaimana agar pembelajaran matematika bisa diserap dengan mudah oleh siswa. Prinsip-prinsip matematika banyak digunakan dalam beberapa alat yang dapat membantu manusia dalam kehidupan sehari-harinya, seperti kalkulator, komputer, dan lain-lain.

Belajar adalah suatu proses usaha yang dilakukan seseorang untuk memperoleh perubahan tingkah laku yang baru secara keseluruhan, sebagai hasil pengalamannya sendiri dalam interaksi dengan lingkungannya (Slameto, 2010, p.2). Sedangkan menurut Aunurrahman (2009, p.48) belajar dapat didefinisikan sebagai setiap perubahan tingkah laku yang relatif tetap dan terjadi sebagai hasil latihan atau pengalaman. Sehingga dapat disimpulkan, bahwa belajar merupakan suatu usaha untuk memperoleh perubahan tingkah laku seseorang yang berwujud latihan dan pengalaman.

Menurut Depdiknas (2003, p.723) "Matematika adalah ilmu tentang bilangan, hubungan antara bilangan, dan prosedur operasional yang digunakan dalam menyelesaikan masalah mengenai bilangan”. Ditinjau dari struktur dan urutan unsur-unsur pembentuknya.

Russel dalam Hamzah B. Uno (2009, p.108) mendefinisikan bahwa matematika sebagai suatu studi yang dimulai dari pengkajian bagian-bagian yang sangat dikenal menuju arah yang tidak dikenal. Arah yang dikenal itu tersusun baik (konstruktif), secara bertahap menuju arah yang rumit (kompleks) dari bilangan bulat ke bilangan pecah, bilangan riil ke bilangan kompleks, dari penjumlahan dan perkalian ke diferensial dan integral, dan menuju matematika yang lebih tinggi.

Matematika merupakan suatu studi yang digunakan dalam menyelesaian masalah mengenai bilangan dari arah yang dikenal itu tersusun baik (konstruktif), secara bertahap menuju arah yang rumit (kompleks).

Dalam melakukan kegiatan belajar tidak selamanya berhasil, terkadang juga mengalami hambatan-hambatan yang mengakibatkan kegagalan belajar. Secara umum kesulitan belajar matematika dapat dikatakan suatu kondisi dalam pembelajaran yang ditandai dengan adanya hambatanhambatan tertentu dalam mencapai hasil belajar matematika siswa.

Definisi kesulitan belajar pertama kali dikemukakan oleh The United States Office of Education (USOE) pada tahun 1977 yang dikenal denga Public Law (PL) 94-142 yang hampir identik dengan definisi yang dikemukakan oleh The National Advisory Committee on Handicapped Children pada tahun 1967 dalam Mulyono (2003, p.6) mengungkapkan kesulitan belajar adalah suatu gangguan dalam satu atau lebih dari proses psikologis dasar yang mencakup pemahaman dan penggunaan bahasa atau ujaran tulisan. Gangguan ini dalam bentuk menampakkan diri dalam bentuk kesulitan mendengarkan, berpikir, berbicara, membaca, menulis, mengeja, atau berhitung.

Widdiharto (2008, p.8) menyatakan bahwa kesulitan belajar merupakan kurang berhasilnya siswa dalam menguasai konsep, prinsip, atau algoritma penyelesaian masalah, walaupun telah berusaha mempelajarinya, 
dan hal ini ditambah lagi dengan kurangnya seorang siswa dalam mengabstraksi, menggeneralisasi, berpikir deduktif dan mengingat konsep-konsep maupun prinsip-prinsip biasanya akan selalu merasa bahwa suatu pelajaran yang diberikan itu sulit. Anderson \& Krathwohl (2010, p.6) membagi dimensi pengetahuan peserta didik menjadi empat dimensi, yaitu pengetahuan faktual, pengetahuan konseptual, pengetahuan prosedural, dan pengetahuan metakognitif. Untuk mengetahui pengetahuan peserta didik tentang hal-hal tersebut, para peserta didik perlu diberikan persoalan-persoalan matematika yang harus diselesaikannya. Hal ini sejalan dengan pendapat Soon, Lioe, \& Mclnnes (2011, p.1027), "the authors reflected that the short questions posed to students helped to identify students' difficulties and levels of conceptual understanding”.

Berdasarkan hal di atas maka kesulitan belajar merupakan ketidakmampuan siswa dalam menguasai fakta, konsep, prinsip, dan keterampilan.

Terjadinya kesulitan belajar dikarenakan siswa menganggap matematika sebagai mata pelajaran yang sulit dan menakutkan. Ketidakmampuan siswa dalam memahami pengetahuan dasar dan mengaitkan antara pengetahuan baru dengan lamanya sehingga menimbulkan ketidakpahaman atau kejelasan terhadap suatu materi. Gejala kesulitan akan tampak ketika siswa tidak mampu lagi berkosentrasi, sebagian siswa mengalami kelelahan dan kejenuhan, dan sebagian siswa mengeluh merasa kesulitan ketika diberi pekerjaan rumah. Fisik dan mental siswa menjadi tidak siap lagi menerima materi yang diberikan.

Faktor-faktor yang mempengaruhi kesulitan dalam belajar, yaitu faktor intern atau faktor dari dalam diri sendiri dan faktor ekstern yaitu faktor yang timbul dari luar siswa.
Ketidakmampuan guru dalam menciptakan pembelajaran matematika yang menarik, serta belum melibatkan siswa secara aktif menjadikan pembelajaran tidak efektif dan menyebabkan siswa kurang bersemangat, cepat bosan untuk belajar matematika. Hal ini belum sepenuhnya disadari oleh guru, sehingga letak dan penyebab kesulitan belajar yang dialami peserta didik juga belum sepenuhnya teridentifikasi.

Untuk mengetahui pemahaman siswa mengenai materi tertentu, salah satunya guru harus memberikan latihan-latihan soal supaya guru mengetahui kesulitan-kesulitan yang dihadapi oleh siswa dalam mempelajari materi tertentu. Salah satunya guru dengan memberikan latihan soal mengenai materi satuan waktu.

Berdasarkan hasil nilai ujian tengah semester kelas V SDN 007 Balikpapan Tengah mempunyai rata-rata skor 45 di bawah KKM. Materi yang paling banyak tidak dikuasai siswa pada materi satuan waktu. Kriteria Ketuntasan Minimal di SDN 007 Balikpapan Tengah adalah 6,50, siswa mengalami kesulitan yaitu memecahkan masalah yang berkaitan dengan satuan waktu. Beberapa kesulitan dalam mempelajari matematika diantaranya adalah: 1) kesalahan konsep maupun kesulitan memahami konsep yang terkait dengan materi satuan waktu; 2) Ketidakmampuan siswa untuk menentukan tanda waktu; 3) Ketidakmampuan untuk mengingat rumus materi satuan waktu yang diajarkan oleh guru; 4) Ketidakmampuan siswa untuk memecahkan masalah tentang materi satuan waktu dalam bentuk cerita; 5) Ketidakmampuan siswa untuk mengerjakan hitungan dalam waktu.

Tujuan penelitian ini adalah: 1) Mendeskripsikan letak kesulitan belajar matematika siswa kelas V Sekolah Dasar Kota Balikapan pada materi satuan waktu, dan; 2) Mendeskripsikan faktor-faktor yang 
menyebabkan kesulitan belajar matematika siswa kelas V Sekolah Dasar pada materi satuan waktu.

\section{METODE}

Dalam penelitian ini peneliti mengambil jenis penelitian deskriptif dengan pendekatan kualitatif. Penelitian kualitatif mempunyai dua tujuan yaitu pertama menggambarkan dan mengungkapkan, kedua menggambarkan dan menjelaskan. Pendekatan kualitatif bersifat deskriptif dikarenakan penelitian deskriptif ditujukan untuk mendeskripsikan dan menggambarkan fenomena-fenomena yang ada, baik fenomena yang bersifat alamiah ataupun rekayasa manusia. Penelitian ini juga mengkaji bentuk, aktivitas, karakteristik, perubahan, hubungan, kesamaan dan perbedaannya dengan fenomena lainnya (Nana, 2011: pp. 60,71).

Penelitian dilaksanakan pada tanggal 02 samapai 12 november 2015 yang dilaksanakan di SD Negeri 007 Balikpapan tengah. Subyek penelitian ini adalah siswa kelas V SD Negeri 007 Balikpapan Tengah yang berjumlah 58 orang siswa maka peneliti mengambil 58 siswa sebagai sampel.

Prosedur penelitian dilakukan dalam Tiga tahapan. Tahapan pertama, meminta ijin kepada Kepala Sekolah SD 007 Balikpapan Tengah untuk mengadakan penelitian. Tahapan kedua, kajian pustaka dengan mengkaji berbagai teori dan implikasi mengenai kesulitan-kesulitan siswa pada materi satuan. Pada tahapan ketiga, mengumpulkan data atau membuat catatan hasil pengamatan yang dituangkan kedalam catatan dari hasil pengamatan.

Metode pengumpulan data yang diperlukan dalam penelitian ini adalah angket, observasi, tes tulis atau pengamatan dan dokumentasi

\section{Angket}

Angket ini bertujuan untuk mengetahui faktor-faktor penyebab terjadinya kesulitan yang dihadapi siswa kelas V SD Negeri 007 Balikpapan Tengah pada materi satuan waktu.

\section{Observasi}

Pengamatan/observasi adalah suatu teknik yang dilakukan dengan cara mengadakan pengamatan secara teliti serta pencatatan secara sistematis. Lembar observasi digunakan untuk mencatat kegiatan yang dilakukan oleh guru dan siswa dalam proses pembelajaran mengajar dan untuk mengetahui sejauh mana kesulitan belajar siswa dalam belajar matematika pada materi satuan waktu.

\section{Tes Tulis}

Tes tertulis digunakan untuk mengetahui kemampuan peserta didik dalam mengorganisasi pengetahuannya ketika memecahkan masalah. Bentuk tes dalam penelitian ini adalah bentuk essay atau uraian sebanyak 8 soal.

\section{Dokumentasi}

Melalui metode dokumentasi, perolehan data dapat dilakukan dengan penyelidikan benda-benda tertulis. Dokumentasi yang dimaksud adalah untuk memperoleh dan menganalisis data mengenai berbagai aktivitas yang dilakukan oleh para siswa di kelas $\mathrm{V}$, juga untuk memperoleh data mengenai penerapan metode pembelajaran di kelas V.

Target dalam penelitian ini adalah siswa mampu memecahkan masalah mengenai menuliskan tanda waktu yang berbentuk soal cerita, dan siswa mampu menyelesaikan masalah operasi hitung satuan waktu dalam bentuk soal cerita.

Teknik pengolahan data pada tes tulis menggunakan rumus presentase. Sebagaimana yang disebutkan Arikunto (2010: 193) sebagai berikut: 


$$
\text { Persentase }(\%)=\frac{F}{N} \times 100 \%
$$

Keterangan:

$\mathrm{P}=$ Persentase jawaban

$\mathrm{F}=$ Frekuensi jawaban

$\mathrm{N}$ = Banyaknya

Dalam menganalisis data, maka angket yang diedarkan mempunyai lima alternatif jawaban dengan menggunakan skala likert. Hasil evaluasi angket diperoleh dari hasil tes uji coba angket yang berjumlah 30 soal angket, kemudian diuji validitas, dan reliable untuk mendapatkan butir angket yang valid, selanjutnya di ujikan kepada siswa yang menjadi subjek penelitian. Diperoleh bahwa 30 soal angket yang diujicobakan terdapat 29 soal angket yang valid. Setelah dilakukan perhitungan dengan menggunakan rumus alpha terhadap hasil uji coba tes diperoleh $r_{\text {hitung }}=0,95$, sedangkan $r_{\text {tabel }}=0,361$. Jadi $r_{\text {hitung }}>r_{\text {tabel }}$ sehingga dari hasil tersebut tes yang diujicobakan reliabel memiliki reliabilitas yang sangat tinggi.

\section{HASIL DAN PEMBAHASAN}

Berdasarkan analisa data yang diperoleh dari hasil penelitian, ternyata siswakelas V SD Negeri 007 Balikpapan Tengah masih terdapat kesulitan-kesulitan dalam mempelajari matematika khususnya materi satuan waktu dalam bentuk soal cerita.

Tabel 1. Distribusi Jawaban Tes Siswa Kelas XI IPA dalam materi Satuan Waktu

\begin{tabular}{ccc}
\hline No Soal & Frekuensi (F) & Persentase (\%) \\
\hline 1 & 33 & $56,9 \%$ \\
\hline 2 & 6 & $10,35 \%$ \\
\hline 3 & 10 & $17,24 \%$ \\
\hline 4 & 9 & $15,52 \%$ \\
\hline 5 & 22 & $37,93 \%$ \\
\hline 6 & 27 & $46,55 \%$ \\
\hline 7 & 36 & $62,07 \%$ \\
\hline 8 & 53 & $91,38 \%$ \\
\hline
\end{tabular}

Dari hasil Observasi dapat dilihat bahwa adanya kesulitan belajar siswa dalam pelajaran matematika. Hal ini dapat dilihat dari pengamatan soal nomor 8 dimana kemampuan siswa dalam memahami materi satuan waktu masih kurang, dimana sebanyak 53 orang siswa masih dalam kategori belum baik dengan persentase 91,38\% masih belum baik kemampuannya dalam menjawab soal-soal operasi hitung satuan waktu. Dalam hal ini ada beberapa hal yang perlu diperhatikan guru yaitu (1) siswa kurang bisa memahami sekaligus mengerjakan bentuk soal operasi hitung satuan waktu; (2) siswa belum terampil mengubah satuan waktu dari jam ke bentuk detik. Hal ini jadi bahan untuk guru bagaimana caranya siswa bisa mampu menjawab dengan baik contohcontoh soal atau latihan.

Kemudian kemampuan siswa dalam memahami materi peluang masih kurang. Hal itu dapat dilihat dari hasil pengamatan soal nomor 7, dimana 36 orang siswa masih dalam kategori belum baik dalam memahami operasi penjumlahan tentang satuan pengukuran waktu dalam matematika dengan persentase $62,07 \%$. Dalam hal ini ada beberapa hal yang perlu diperhatikan guru yaitu (1) siswa kurang bisa memahami dan mengerjakan operasi hitung satuan waktu dalam operasi penjumlahan, (2) siswa kurang terampil atau mengingat konsep mengubah satuan waktu dari windu ke dalam bentuk tahun.

Kemudian siswa juga masih kurang melakukan pembelajaran aktif di dalam kelas ketika diberikan pelajaran. Hasil ini dapat dilihat dari hasil pengamatan soal nomor 1, dimana sebanyak 33 orang siswa masih kurang baik dalam menggambar satuan waktu dengan persentase 56,9\%. Hal ini siswa kurang bisa mengingat konsep atau kurang terampil dalam menggambar jam, siswa juga kurang bisa memahami makna bentuk soal sehingga siswa sering 
keliru menggambar jam. Disini guru perlu melihat apa kendala yang dialami siswa sehingga dengan ini guru dapat dengan mudah mengaktifkan belajar siswa dalam kelas dan memberikan contoh dan latihan soal yang bervariasi.

Aspek pengamatan soal nomor 6, dapat dilihat bahwa siswa belum baik dalam menyimak pertanyaan berhubungan dengan pelajaran, dimana sebanyak 27 orang siswa masih dalam kategori kurang baik dengan persentase $46,55 \%$. Dalam hal ini siswa kurang terampil dalam mengerjakan soal operasi hitung satuan waktu dalam bentuk operasi pengurangan dan siswa kurang memahami soal cerita. Disini siswa kurang menyimak pertanyaan yang berhubungan dengan pelajaran, oleh karena itu guru harus lebih aktif dalam proses belajar mengajar dimana guru harus mengubah kebiasaan siswa dalam berpikir matematika. Hasil jawaban siswa akan dibahas secara lebih baik dengan mencantumkan langsung hasil tes siswa dalam bentuk gambar, berikut pemaparan hasil tes siswanya.

Dari hasil jawaban siswa diatas bisa dilihat bahwa siswa belum bisa memahami soal dengan baik, siswa hanya benar ketika memisalkan sataun waktu tersebut, siswa salah dalam membuat rumus operasi hitung satuan waktu, mengubah satuan waktu, menggambar satuan waktu, dan memahami soal cerita satuan waktu/operasi hitung satuan waktu. Kemudian ketika siswa memasukkan nilai penyelesaiannya tersebut benar akan tetapi siswa salah dalam penentuan hasil akhir sehingga membuat hasil yang didapat siswa tidak seperti yang diharapkan atau salah. sehingga bisa diambil kesimpulan bahwa siswa masih belum bisa memahami satuan waktu dengan baik.
Pada soal nomor 5, sebanyak 22 orang atau $37,93 \%$ siswa mengalami kesulitan dalam menyelesaikan satuan waktu. Siswa salah memasukkan rumus sebenarnya, dimana seharusnya siswa menggunakan operasi pengurangan, tetapi siswa menggunakan rumus operasi penjumlahan, sehingga membuat hasil penyelesaiannya juga salah. Dari penyelesaian soal tersebut dapat dilihat kemampuan siswa dalam memahami soal satuan waktu ini masih sangat kurang atau masih dalam kategori sulit.

Pada soal nomor 3, sebanyak 10 siswa atau $17,24 \%$ siswa mengalami kesulitan dalam menyelesaikan soal satuan waktu. Dari hasil jawaban siswa tersebut dapat dilihat bahwa kesulitan siswa dalam menjawab soal ini, siswa benar-benar tidak paham dengan penulisan notasi satuan waktu tersebut. Siswa bingung menuliskan notasi satuan waktu 24 jam.

Pada soal nomor 4, sebanyak 9 siswa atau $15,52 \%$ siswa mengalami kesulitan dalam menyelesaikan soal satuan waktu. Dari hasil jawaban soal nomor 4 dapat diketahui bahwa kesulitan siswa adalah karena kurangnya pemahaman siswa dalam memahami konsep materi satuan waktu sehingga siswa terkadang bingung menuliskan satuan waktu notasi 24 jam diubah menjadi notasi 12 jam.

Pada soal nomor 2, sebanyak 10 siswa atau $10,35 \%$ siswa mengalami kesulitan dalam manuliskan notasi satuan waktu 24 jam diubah menjadi notasi 12 jam. Siswa masih salah dalam menuliskan notasi satuan waktu, salah menuliskan angka pada notasi satuan waktu, dan siswa harus menuliskan notasi 12 jam tetapi siswa salah memahami soal cerita dalam satuan waktu. 
Tabel 2. Letak Kesulitan

Belajar Matematika Siswa

\begin{tabular}{lc}
\hline \multicolumn{1}{c}{ Objek Langsung } & Persentase \\
\hline Fakta & $14,4 \%$ \\
\hline Konsep & $56,9 \%$ \\
\hline Keterampilan & $42,2 \%$ \\
\hline Prinsip & $76,7 \%$ \\
\hline
\end{tabular}

Dari hasil penelitian diperoleh kesimpulan bahwa kesulitan mahasiswa berdasarkan hasil tes, yaitu: kesulitan materi satuan waktu dengan rata-rata sebesar 47,55\%. Letak kesulitan belajar matematika yang dialami siswa adalah fakta, konsep, keterampilan dan prinsip. Kesulitan siswa dalam fakta sebesar 14,4\% dikategorikan sangat rendah. Dalam hal ini siswa yang tidak dapat/keliru menangkap fakta yang diberikan oleh soal, baik informasi mengenai apa yang diketahui maupun yang ditanya pada soal, siswa mengalami kesulitan/ kesalahan dalam penggunaan simbol-simbol yang merupakan fakta dalam matematika. Seperti keliru menuliskan tanda waktu dan keliru menuliskan notasi angka.

Kesulitan siswa dalam pemahaman konsep sebesar 56,9\% termasuk kategori tinggi. Siswa keliru dalam menggambar jam. Informasi yang diminta dalam menggambar jam adalah pukul 9 kurang $\frac{1}{4}$ jam. Tetapi siswa menggambarkan pukul 9 lebih $\frac{1}{4}$ jam. Dalam hal ini siswa kurang mengerti dalam pemahaman konsep, siswa sudah tahu bahwa $\frac{1}{4}$ jam adalah 15 menit, tetapi salah dalam menggambar jam.

Berdasarkan kesulitan siswa dalam keterampilan sebesar 42,2\% dikategorikan tingkat kesulitan belajar matematika siswa cukup. Siswa sudah bisa menghitung tanpa menggunakan kalkulator, tetapi siswa salah dalam menentukan hasil penyelesaiannya. Dalam operasi hitung satuan waktu, siswa telah benar dalam menuliskan operasi pengurangan, tetapi siswa salah dalam melakukan operasi pengurangan dalam satuan waktu.

Kesulitan siswa dalam prinsip sebesar $76,7 \%$ termasuk kategori tinggi. Dalam hal ini siswa tidak mengerti apa yang ditanyakan pada lembar soal. Siswa juga tidak bisa mengubah satuan waktu, misalnya saja windu diubah menjadi tahun, serta tidak bisa mengubah satuan waktu bulan menjadi tahun. Ada beberapa siswa tidak mengerti apa yang ditanyakan pada lembar soal yang memuat dua konsep karena siswa merasa bingung dalam memahami pertanyaan pada lembar soal, tidak menghafal rumus satuan waktu, dan siswa juga kurang mengerti penggunaan operasi hitung satuan waktu. Dalam hal ini siswa kesulitan dalam menghafal satuan waktu dan kurang terampil dalam mengerjakan soal yang memuat dua konsep.

Dari hasil pembahasan tes bisa diambil kesimpulan bahwa siswa tidak memahami materi satuan dalam bentuk soal cerita dengan baik, siswa masih banyak salah dalam memasukkan rumus dan sering berbalik antara operasi pengurangan dengan operasi penjumlahan dan mengubah satuan waktu dengan mengubah detik menjadi jam atau windu ke tahun, sehingga siswa banyak salah dalam menjawab soal, ini juga diakibatkan karena cara guru mengajar hanya dengan cara mencatat di papan tulis sesuai dari hasil yang di dapat dari angket, sehingga siswa tidak bisa memahami soal cerita satuan waktu dengan baik, dan ini merupakan sebuah faktor kesulitan besar siswa dalam belajar materi satuan. Kesulitan siswa dalam materi satuan waktu ini lebih dominan pada pembahasan penggunaan operasi hitung satuan waktu, mengubah ukuran waktu, menuliskan notasi satuan waktu, dan menggambar satuan waktu.

Berdasar hasil pembahasan angket di atas dapat diambil kesimpulan, bahwa ada 
beberapa faktor kesulitan siswa dalam belajar matematika khususnya materi satuan waktu yaitu faktor intern atau faktor dari dalam diri sendiri dan faktor ekstern yaitu faktor yang timbul dari luar siswa.

Faktor intern yang mempengaruhi kesulitan belajar siswa adalah: (1) siswa kurang minat belajar matematika dikarenakan nilai matematika selalu rendah, (2) kurang berminat dalam belajar kelompok, dan (3) banyak rumus yang harus dihafalkan serta catatan matematika yang diberikan guru terlalu banyak. Sedangkan faktor ekstern yang mempengaruhi kesulitan belajar adalah: (1) guru tidak menggunakan alat peraga sehingga saya kurang mengerti, (2) buku-buku pelajaran matematika yang disediakan kurang lengkap, (3) metode yang digunakan guru dalam menerangkan satuan waktu kurang menarik, dan (4) ketika guru memberikan tugas atau latihan ada beberapa siswa yang asik bermain dengan temannya sehingga tugas atau latihan tidak selesai dengan baik.

Dari kesimpulan tes, angket dan observasi diatas bisa diambil kesimpulan bahwa kesulitan siswa kelas $\mathrm{V}$ dalam materi satuan waktu adalah kurangnya pemahaman siswa dalam memahami konsep satuan waktu, sering salah dalam penggunaan rumus, juga kebiasaan guru dalam belajar matematika hanya dengan cara mencatat saja di papan tulis, kemudian siswa kurang keinginannya dalam menyelesaikan contoh soal yang diberikan oleh guru.

\section{SIMPULAN}

Berdasarkan hasil analisis data, maka dapat diambil simpulan : 1) Letak kesulitan belajar matematika yang dialami siswa diantaranya dalam hal fakta, konsep, keterampilan dan prinsip: (a) Kesulitan siswa dalam fakta sebesar 14,4\% termasuk kategori sangat rendah. Siswa yang tidak dapat/keliru menangkap fakta yang diberikan oleh soal, baik informasi mengenai apa yang diketahui maupun yang ditanya pada soal, siswa mengalami kesulitan/kesalahan dalam penggunaan simbol-simbol yang merupakan fakta dalam matematika, (b) Kesulitan siswa dalam pemahaman konsep sebesar 56,9 \% termasuk kategori tinggi. Siswa salah atau keliru dalam menggambar jam, siswa sudah bisa menghitung waktu tetapi untuk diterapkan dalam gambar terkadang sering keliru, (c) Kesulitan siswa dalam keterampilan sebesar $42,2 \%$ termasuk kategori cukup. Siswa sudah bisa menghitung tanpa menggunakan kalkulator, tetapi siswa salah dalam menentukan hasil penyelesaiannya, (d) Kesulitan siswa dalam prinsip sebesar $76,7 \%$ termasuk kategori tinggi. Siswa juga tidak bisa mengubah satuan waktu, misalnya saja windu diubah menjadi tahun, atau tidak bisa mengubah satuan waktu bulan menjadi tahun, kurangnya pemahaman siswa dalam memahami lembar soal yang memuat dua konsep; 2) Faktor-faktor yang menyebabkan peserta didik mengalami kesulitan dalam belajar pada materi satuan waktu yaitu faktor intern dan ekstern: (a) Faktor intern yang menyebabkan kesulitan belajar siswa diantaranya siswa kurang minat belajar matematika dikarenakan nilai matematika selalu rendah, kurang berminat dalam belajar kelompok, banyak rumus yang harus dihafalkan serta catatan matematika yang diberikan guru terlalu banyak, (b) Faktor ekstern yang menyebabkan kesulitan belajar matematika meliputi: guru tidak mengguna-kan alat peraga sehingga saya kurang mengerti, buku-buku pelajaran matematika yang disediakan kurang lengkap, metode yang digunakan guru dalam menerangkan satuan waktu kurang menarik, dan kurang-nya perhatian guru kepada peserta didik yang tingkat kemampuan pemahamannya rendah. 


\section{DAFTAR PUSTAKA}

Anderson, L. W., \& Krathwohl, D. R. 2010. Kerangka landasan untuk pembelajaran, pengajaran, dan asesmen: revisi taksonomi pendidikan bloom. (Terjemahan Agung Prihantoro). New York: Pearson Addison-Wesley. (Buku asli diterbitkan tahun 2001)

Ardiansyah, Gigih Sudarka. 2014. Kesulitan Belajar Matematika Siswa Kelas VIII Sekolah Menengah Pertama Negeri 1 Sambi Tahun 2013/20014. Skripsi, tidak dipublikasi. Universitas Muhammadiyah Surakarta.

Arikunto, Suharsimi. 2010. Prosedur Penelitian Suatu Pendekatan Praktik. Jakarta: Rineka Cipta.

Aunurrahman. 2009. Belajar dan Pembelajaran. Bandung: Alfabeta.

Depdiknas. 2003. Panduan Pengembangan Silabus Mata Pelajaran Matematika. Jakarta: Depdiknas - Dirjen Dikdasmen. Jamal, Fakhrul. 2014. Analisis Kesulitan Belajar Siswa dalam Mata Pelajaran Matematika Pada Materi Peluang Kelas
XI IPA SMA Muhammadiyah Meulaboh Johan Pahlawan. Jurnal MAJU, 1 (1), 18-36.

Soon, W., Lioe, L, T., \& Mclnnes, B. 2011. Understanding the difficulties faced by engineering undergraduates in learning mathematical modelling. International Journal of Mathematical Education in Science and Technology. 42, 10231039.

Sukmadinata, Nana Syaodih, 2011, Metode Penelitian Pendidikan, Bandung: PT. Remaja Rosda Karya.

Uno, Hamzah B. Uno dan Masri Kuadrat. 2009. Mengelola Kecerdasan dalam Pembelajaran. Jakarta: PT. Rineka Cipta.

Widdiharto, Rachmadi. 2008. Diagnosis Kesulitan Belajar Matematika SMP dan Alternatif Proses Remidinya. Yogyakarta: Pusat Pengembangan dan Pemberdayaan Pendidik dan Tenaga Kependidikan Matematika. 